DOI: $10.20472 / B M .2021 .9 .1 .002$

\title{
FINANCIAL PERFORMANCE OF SPU MULTIPURPOSE COOPERATIVE : A TEST OF SUSTAINABILITY
}

\section{CHARITO GUILLERMO}

\begin{abstract}
:
The study aimed to determine the financial performance of SPU Multipurpose Cooperative, Incorporated SPUMC based on the standard set by the Cooperative Development Authority. The case analysis approach was employed specifically the Financial Statement Analyses, Ratio Analysis and SWOT Analysis to determine the current financial status, capability and performance of the cooperative for the last ten operating periods: 2006-2015. The Cooperative Development Authority (CDA) Standards was used to determine compliance in terms of financial aspect, the CDA performance index was used to determine level of sustainability while the formula of Kinde (2012) was used to measure financial sustainability. Results show that SPUMC, keeps as a strategy the implementation of very conservative working capital management, remains to be capable of meeting the demands of the current times given its financial performance on the different financial indicators as prescribed by the CDA. Moreover, this study show that despite of the cooperative's slow growth, having reached its maturity in its life cycle, its financial performance for the ten year period indicates that it has the capability to sustain its services as it is financially sustainable.
\end{abstract}

\section{Keywords:}

Financial performance, profitability, institutional strength, structure of assets, Operational Strength

JEL Classification: P13, O43, L30

\section{Authors:}

CHARITO GUILLERMO, St. Paul University Philippines, Philippines, Email: cmguillermo@spup.edu.ph

\section{Citation:}

CHARITO GUILLERMO (2021). FINANCIAL PERFORMANCE OF SPU MULTIPURPOSE COOPERATIVE : A TEST OF SUSTAINABILITY. International Journal of Business and Management, Vol. IX(1), pp. 34-46., 10.20472/BM.2021.9.1.002 


\section{Introduction}

A cooperative business, also known as a co-op, is a type of organization that is both owned and controlled by its members, who also happen to use the services and products of the cooperative. LaMarco, (2018). In many ways a cooperative is like any other business; but in several important ways it is unique and different. A cooperative business belongs to the people who use it-people who have organized to provide themselves with the goods and services they need. The President of the Philippines has shown his recognition of the important role of Cooperatives in the country's quest for development. In the Message of President to the Aurora integrated multipurpose cooperative on the occasion of their 45th annual representative assembly, March 16, 2013. Aquino (2013) said that in the important role that cooperatives play in our quest for equitable progress, cooperatives do espouse the principles of shared responsibility and collective ownership in the management of their resources, and rise together with their respective communities. These goals are the core of the government's agenda to usher in prosperity that is encompassing and inclusive, where no one is left behind as the nation realizes its fullest potential. He further said that may the occasion sustain the momentum of the cooperative's expansion across the archipelago, that they may change the lives of more of the Filipino people. Similarly, in the message of President Aquino to the Sta. Ana Multipurpose Cooperative (SAMULCO) on their 46th general assembly, April 7, 2013, he also recognized cooperatives as partners where he said: "we are grateful to have you as partners in uplifting the lives of our countrymen and making them productive members of society. May you be able to sustain your Cooperative's success and promote inclusive economic growth and equitable progress for the benefit not only of your locality, but of the entire nation". In the assembly of representatives in October 31 of the United Nations (2011), significant reference was made again about the important role of cooperatives. There, it was mentioned that the event was to raise awareness about the impact of cooperatives on the development of communities where they operate. "Cooperative enterprises build a better world" is the theme for the first International Year of Cooperatives (IYC). Cooperatives operate for the benefit of memberowners. In a cooperative, those with similar needs act together and pool their resources for mutual gain. But the returns are not just monetary. Members ensure that their cooperative business provides the best quality products and services at the lowest possible cost. Members control the business through participation in their cooperative; they extend democratic practice into their economic lives. Cooperative work together on the local, regional and national level to promote exchange among cooperatives, foster cooperative development, provide educational services, and provide a forum for examining and acting on common concerns for cooperatives. In addition, cooperatives are established as an arm of the government in nation building through the various services that are offered to the members and to other stakeholders. Numerous cooperative associations throughout the Philippines provide industry-specific services, educational programs, and financial and other services to their member cooperatives.

St. Paul University Multipurpose Cooperative (SPUMC) is one of the recognized cooperatives in the country, located in Region 2. SPUMC was incorporated pursuant to Republic Act No. 6938, otherwise known as the Cooperative Code of the Philippines. It was established for the purpose of encouraging thrift and savings mobilization, granting loans to members for productive, educational and providential purpose, providing goods and services and other requirements of the members, among others. SPUMC was organized as a stock, nonprofit organization under the certificate of registration No. 9520-02000436 issued by the CDA on October 12, 2009. The original CDA Registration No. Was R-II-FF-249 issued on February 8, 1988. It was formed as primary multipurpose cooperative with area of operation in Tuguegarao City and with a corporate life of 50 years from the date of and after its incorporation. The 
SPUMC have at present four employees. As of December 31, 2015, the services offered are time deposits, special loan, lot loan, laptop loan, grocery loan, educational loan, house improvement loan, car loan, emergency loan, regular loan, calamity loan, medical loan, and appliance loan. Having its members the past as well as present employees of St. Paul University Philippines, the cooperative records show an increase in number of membership: from 330 members in 2010, down to 314 in 2012 to 340 in 2014, increase in services offered to members, as well as increase in its capitalization. SPUMC boasts the following services to its members: emergency loans, regular loans, special loans, educational loans, car loans, grocery loans among others, all with one end goal, to uplift the lives of the members and build a better nation.

Buranapin \& Ratthawatankul (2015) presented in their study on Business sustainability that the general definitions of business sustainability are based on Brundtland's report that defines sustainable development as "an operation that meets the need of the present, without compromising the ability of future generations to meet their own needs" (WCED, 1987). Business sustainability is defined as the activities of companies demonstrating the inclusion of social and environmental concerns in business operations, and in interactions with stakeholders (Kotier et al. 2010; Marrewijk, 2002; Werre, 2003). The triple bottom line, which combines economic, social and environmental aspects, is a simplified way to address sustainability's three primary components (Avery 2005, Brown et al. 2006, Robinson et al. 2006). For business sustainability, firms gain superior performance from simultaneously exploiting their existing resources in the current competitive landscape and exploring new opportunities for the future (Levinthal \& March 1993; March,1991; O'Reilly \& Tushman, 2004; Raisch et al. 2009). From an economic perspective, firms can be more sustainable by gaining both profitability and growth (Gupta \& Govindarajan, 1986; Han, 2007; Han \& Celly, 2008; Lubatkin et al. 2006). These two economic indicators are paradoxical. Profitability focuses on achieving financial performance and can be measured as profit, profit margin, and return on investment (ROI), whereas growth focuses on achieving marketing performance and can be measured as market share, growth in market share, sales growth and new market creation (Han \& Celly, 2008). According to this explanation, profit is regard as exploitation and growth refers to exploration.

The capability of SPUMC to meet the demands of the stakeholders is dependent on the answers to the questions such as how well it is doing, is it meeting its goals, are the customers still satisfied, are the processes in statistical control, and whether there is a need to improve somewhere, and how will it become better.

It is for the above reasons that the researcher embarked on this endeavour: to find out the cooperative's capability of sustaining its life so as to serve better its stakeholder as well as for the researcher to have a baseline data and come up with a set of recommendation for the cooperative with the hopes of making the cooperative operate better for the benefit of the stakeholders, the community and the country as a whole.

\section{Theoretical/ Conceptual Framework}

Sustainability relates to the ability of a program to continuously maintain its activities and services in order to meet its objectives. In so doing, for an organization to be sustainable, it must have sufficient resources and the efficient utilization of these resources in order to achieve its mission and goals. The goal of sustainability requires a more extended timeline for return on investment (ROI) but once initial investments are made, they can actually lead to increased profitability. Sustainable Business essentially means being able to continue, or operating in a way that is conducive to ongoing trading. 


\section{Statement of the Problem}

The study aimed to determine the financial performance of St. Paul University Multipurpose Cooperative, Incorporated. Specifically, it aimed to seek and provide answers to the following questions:

1. What is the performance of St. Paul University Multipurpose Cooperative, Incorporated as to

1.1 Profitability

1.2 Institutional Strength

1.3 Structure of Assets

1.4 Operational Strength

2. What is the performance of St. Paul University Multipurpose Cooperative, Incorporated when compared to the Cooperative Development Authority Standards?

3. What is the sustainability index of SPU Cooperative?

\section{METHODOLOGY}

\section{Research Design}

The researcher used the descriptive design, specifically the evaluative design to appraise the worthiness of the current study.

\section{Research Instruments}

The data pertinent to the study were obtained through documentary analysis of the audited financial statements of the cooperative for a period of ten (10) years.

\section{Data Collection Procedure}

The researcher sought the recommendation of the Director for Research and Publication of St. Paul University Philippines to present the Research proposal before a Panel for approval. Upon approval of the research proposal, the researcher wrote a letter to the Board of Directors and to the management of SPU Multipurpose Cooperative seeking their approval as to conduct of the study, as well as to the access to the pertinent documents of the SPU Cooperative as needed for the conduct of the study.

The researcher did the Case analysis Approach, using Financial Statement Analysis; Ratio Analysis and SWOT Analysis to determine the present financial status, capability and performance of the SPU Multipurpose cooperative towards financial sustainability. Furthermore, the researcher also did the Performance Assessment and Analysis finally using the Performance Report Standards for Cooperatives (memorandum circular No. 2013-2015, series of 2013 of the CDA Philippines.

\section{Data Analysis}

The following statistical tools were used to analyze and interpret the data collected and organized:

1. Financial Statement Analysis and Other Relevant Ratio Analysis. These were used to analyze the financial performance of SPU Multipurpose Cooperative.

2. The Cooperative Development Authority Standards (CDA Standards) was used to determine the compliance of SPU Multipurpose Cooperative. 
3. The CDA performance index was used to determine the level of sustainability of the SPUMCI based on its performance.

4. The formula presented by Kinde, 2012 was used to measure the financial sustainability.

5. For the Ratio Analysis using the CDA standards, computations were made in accordance to the CDA prescribed specific formula.

The CDA Standards utilized in the study as a basis of measuring the cooperative's financial performance is reflected in memorandum circular No. 2013-2015, series of 2013 of the CDA Philippines. This indicates the standard points and the corresponding rating the organization achieves for each item indicated along Profitabitly Performance, Institutional Strength, Structure of Assets and Operational Strength also known as the orgaizations' Staying Power. After perfroming ratio analysis under each financial measure, the researcher then interpreted the results using the adjectival rating indicated in the CDA standard such as Excellent Performance for a rating of $91 \%-100 \%$; Very Satisfactory Performace for a rating of $81 \%-90 \%$; satisfactory if the rating is $71 \%-80 \%$; Fair Performace if rating falls within tha ratings $61 \%-70 \%$, while Needs improvement if rating is $60 \%$ and below.

\section{RESULTS AND DISCUSSION}

\section{Performance of St. Paul University Multipurpose Cooperative, Incorporated as to Profitability}

As to profitability, (Table 1) the cooperative is rated Excellent under Profitability Ratio (Figure 1), having an average performance of .467 rated as 5 . It got a rating of Excellent on Rate of Interest on share capital having an average of $2.52 \%$ for the last 10 years. This rate is higher than the current inflation rate which is $1.5 \%$ in July of 2016 . However, of the five measures of profitability performance, the SPUMC had an average rating of Needs Improvement in three categories: Earnings Per Share (EPS), Profitability Growth Rate (Figure 2) and Asset Efficiency Rate (Return on Assets).

Figure 1

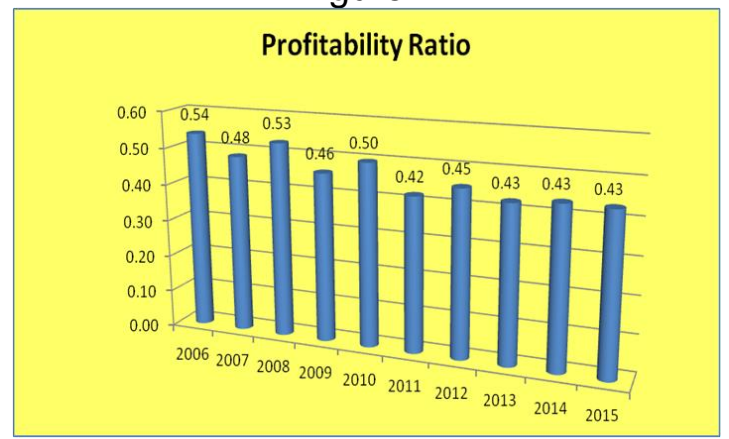

Figure 2

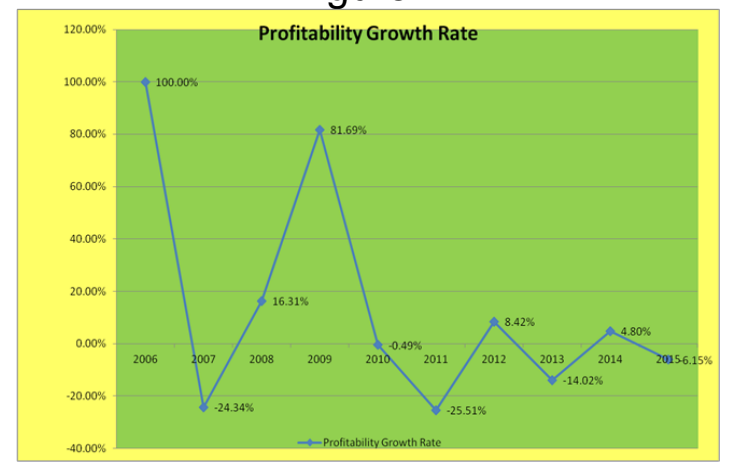


Table 1 Performance of St. Paul University Multipurpose Cooperative, Incorporated as to Profitability

\begin{tabular}{|c|c|c|c|c|}
\hline & Average & $\begin{array}{c}\text { CDA } \\
\text { Performance } \\
\text { Index }\end{array}$ & $\begin{array}{c}\text { CDA } \\
\text { Performance } \\
\text { Rating }\end{array}$ & $\begin{array}{c}\text { Adjectival } \\
\text { Rating }\end{array}$ \\
\hline Profitability Ratio & 0.467 & 5 & $100 \%$ & Excellent \\
\hline $\begin{array}{l}\text { Earnings Per Share } \\
\text { (EPS) }\end{array}$ & 0.108 & 1 & $20 \%$ & $\begin{array}{c}\text { Needs } \\
\text { Improvement }\end{array}$ \\
\hline Profitability Growth Rate & $14.07 \%$ & 1 & $20 \%$ & $\begin{array}{c}\text { Needs } \\
\text { Improvement }\end{array}$ \\
\hline $\begin{array}{l}\text { Asset Efficiency Rate } \\
\text { (Return on Assets) }\end{array}$ & $6.90 \%$ & 2 & $40 \%$ & $\begin{array}{c}\text { Needs } \\
\text { Improvement }\end{array}$ \\
\hline $\begin{array}{l}\text { Rate of Interest on Share } \\
\text { Capital }\end{array}$ & $2.52 \%$ & 5 & $100 \%$ & Excellent \\
\hline Total & & 14 & $56 \%$ & $\begin{array}{c}\text { Needs } \\
\text { Improvemen }\end{array}$ \\
\hline
\end{tabular}

\section{Institutional Strength}

The Net Institutional Capital has an average of $4.53 \%$. This computed value is given 3 points in the CDA Performance Rating, with 6 points as the highest. It turns out that on the average, the SPUMC has performed Fair only as to the performance measure on institutional strength. As regards adequacy of provisioning as one measure of Institutional Strength, the cooperative has averaged at $30.36 \%$. This implies that a significant portion of total past due accounts (averaging 69.64\%) has no corresponding provisioning. This percentage got a total of 6 points only as per CDA standards. This is barely $43 \%$ of the highest rating possible, and it has an adjectival rating of Needs Improvement. In general, the performance of the SPUMC in terms of Institutional Strength is rated as Needing Improvement.

Figure 3

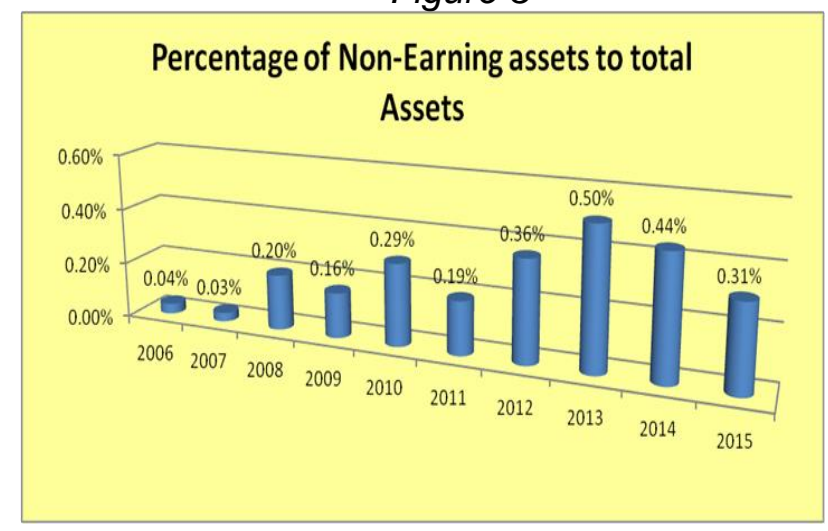


Table 2 Structure of Assets

\begin{tabular}{|c|c|c|c|c|}
\hline & Average & $\begin{array}{c}\text { CDA } \\
\text { Performance } \\
\text { Index }\end{array}$ & $\begin{array}{c}\text { CDA } \\
\text { Performance } \\
\text { Rating }\end{array}$ & $\begin{array}{l}\text { Adjectival } \\
\text { Rating }\end{array}$ \\
\hline $\begin{array}{l}\text { 3.1 Percentage of } \\
\text { Non-Earning assets } \\
\text { to total Assets }\end{array}$ & $0.25 \%$ & 5 & $100 \%$ & Excellent \\
\hline $\begin{array}{l}3.2 \text { Members' } \\
\text { Equity to Total } \\
\text { Assets }\end{array}$ & $65.98 \%$ & 2 & $40 \%$ & $\begin{array}{l}\text { Needs } \\
\text { Improvement }\end{array}$ \\
\hline $\begin{array}{l}\text { 3.3 Deposit } \\
\text { Liabilities to Total } \\
\text { Assets }\end{array}$ & $11.61 \%$ & 3 & $60 \%$ & $\begin{array}{l}\text { Needs } \\
\text { Improvement }\end{array}$ \\
\hline $\begin{array}{l}3.4 \text { Receivables to } \\
\text { Total Assets }\end{array}$ & $88.82 \%$ & 5 & $100 \%$ & Excellent \\
\hline $\begin{array}{l}\text { External } \\
\text { Borrowings }\end{array}$ & 0 & 5 & $100 \%$ & Excellent \\
\hline Total & & 20 & $80 \%$ & Satisfactory \\
\hline
\end{tabular}

Of the five measures of performance under Structure of Assets, (Table 2) three (3) of these were rated as Excellent: Percentage of Non-Earning assets to total Assets, having an average of $0.25 \%$;Receivables to Total Assets with an average of $88.82 \%$ and for having zero External Borrowings. The two measures of performance under structure of assets which are the Members' Equity to Total Assets, having an average 65.98\%; and Deposit Liabilities to Total Assets with an average $11.61 \%$ were given 2 points and 3 points respectively. This ratings merited a Needs Improvement adjectival rating using the CDA standards. In general, the SPUPMC got a rating of Satisfactory in the performance measurement standards of CDA under Structure of Assets after having garnered a total of 20 points or $80 \%$ average rating.

\section{Operational Strength}

Of the six measures of operational strength, SPUMC rated excellent in the areas Volume of Business to Total Assets; Solvency (figure 4); Cost per Volume of Business and administrative efficiency. This implies that the cooperative has a very strong standing financially along its conduct of business: in that, it is able to maximize the use of its assets for its current operations. The results also show that the cooperative is very much capable in paying its maturing obligations and has still sufficient assets for capital liquidation. It further implies that administrative costs spent is minimal in comparison to the total assets of the cooperative. It is to be noted however that along liquidity and turn over ratio, the cooperative rated as need improvement. Liquidity ratio (figure 5) scoring shows that the cooperative is more than enough capacity to pay its currently maturing obligation that most current assets' use is not maximized. As to turn-over ratio, the cooperative is rated with the lowest point. It implies that there is a slow movement in terms of collection of loan releases, thereby increasing the investment of the cooperative to receivables. This result matches with that of the high amount of receivables that are doubtful of collection. Such increase in doubtful accounts with insufficient provision contribute to a high amount of receivables thereby decreasing the turn over ratio. 
Figure 4

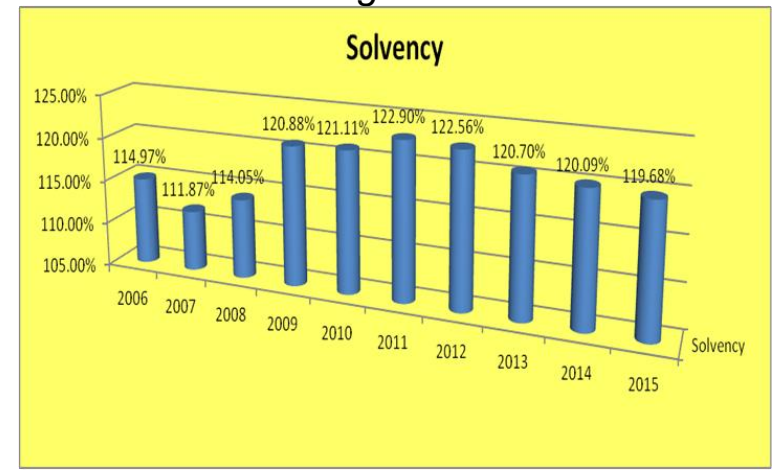

Figure 5

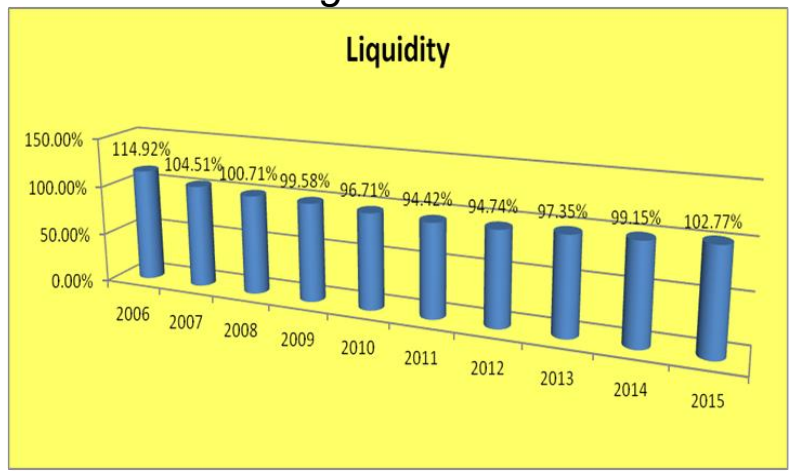

Table 3 Operational Strength

\begin{tabular}{|c|c|c|c|c|}
\hline & Average & $\begin{array}{c}\text { CDA } \\
\text { Performanc } \\
\text { e Index }\end{array}$ & $\begin{array}{c}\text { CDA } \\
\text { Performa } \\
\text { nce } \\
\text { Rating }\end{array}$ & $\begin{array}{l}\text { Adjectival } \\
\text { Rating }\end{array}$ \\
\hline $\begin{array}{l}\text { 4.1 Volume of Business to } \\
\text { Total Assets }\end{array}$ & $143.26 \%$ & 5 & $100 \%$ & Excellent \\
\hline 4.2 Solvency & $118.88 \%$ & 5 & $100 \%$ & Excellent \\
\hline 4.3 Liquidity & $100.49 \%$ & 1 & $20 \%$ & $\begin{array}{l}\text { Needs } \\
\text { Improvement }\end{array}$ \\
\hline $\begin{array}{l}4.4 \text { Cost per Volume of } \\
\text { Business }\end{array}$ & .0410 & 5 & $100 \%$ & Excellent \\
\hline 4.5 Administrative Efficiency & $5.55 \%$ & 5 & $100 \%$ & Excellent \\
\hline 4.6 Turn Over Ratio & 1.60 times & 1 & $20 \%$ & $\begin{array}{c}\text { Needs } \\
\text { Improvement }\end{array}$ \\
\hline Total & & 22 & $73.33 \%$ & \\
\hline
\end{tabular}




\section{Performance of St. Paul University Multipurpose Cooperative, Incorporated when compared to the Cooperative Development Authority Standards.}

In the rubric used to measure Financial Performance of cooperatives, CDA measures financial performance under four categories: Profitability; Institutional Strength; Structure of Assets and Operational Strength (Staying Power). Results show that as to Profitability, the cooperative rated as Need Improvement, having obtained a total of 14 points of a total 25 points along this area. The same rating of Need Improvement is given to the cooperative as to institutional strength, having obtained a total point of 9 of a total of 20 points along this area. In terms of Structure of assets, the cooperative got an average of 20 over 25 points, earning it a rating of satisfactory. As to operational strength, the cooperative also rated with satisfactory performance, having averaged with 22 points over 30 points. Given the above points for the financial performance measurement of the cooperative, these have contributed to a total of 65 points over all performance, or $65 \%$ rating based on the CDA standards. This rating $(65 \%)$ is given an adjectival rating of Fair using the standards of the CDA. This implies that the cooperative still has a long way to go in terms of improving its performance so as to achieve sustainability and be able to meet it objectives and goals in accordance too, to regulating bodies such as the Cooperative Development Authority. This result further imply that Top Management has to continue in its efforts to improve performance and be able to meet the acceptable standards for a medium to large enterprise category to where the SPUMC belong.

Table 4 Performance of St. Paul University Multipurpose Cooperative, Incorporated when compared to the Cooperative Development Authority Standards.

\begin{tabular}{lccc}
\hline CDA Measure of Performance & $\begin{array}{c}\text { SPUMC } \\
\text { Score }\end{array}$ & $\begin{array}{c}\text { CDA } \\
\text { Score }\end{array}$ & CDA Rating \\
\hline 1. Profitability & $(14)$ & $(25)$ & $\begin{array}{c}\text { Need } \\
\text { Improvement } \\
\text { 2. Institutional Strength }\end{array}$ \\
3. Structure of Assets & $(9)$ & $(20)$ & $\begin{array}{c}\text { Need } \\
\text { Improvement }\end{array}$ \\
4. Operational Strength & $(20)$ & $(25)$ & Satisfactory \\
\hline Total & $(22)$ & $(30)$ & Satisfactory \\
\hline
\end{tabular}

\section{Sustainability index of SPU Cooperative}

The SPUMC has high sustainability indexes for the last 10 years in both operational sustainability and financial self sufficiency. In the CDA standards, the equivalent measurement for sustainability is the Operational Strength, also described as Staying Power. Of the six (6) measures of staying power, the SPUMC got an excellent rating in 4 measures. This indicates that the cooperative has the ability to sustain its operations if it performs even better in the future operations and when management is able to find ways by which the liquidity and turn over ratio will improve. According to the Dow Jones(2015),_corporate sustainability "is a business approach that creates long-term shareholder value by embracing opportunities and managing risks deriving from economic, environmental and social developments. Corporate sustainability leaders achieve long-term shareholder value by gearing their strategies and management to harness the market's potential for sustainability products and services while at the same time successfully reducing and avoiding sustainability costs and risks." 
Figure 6

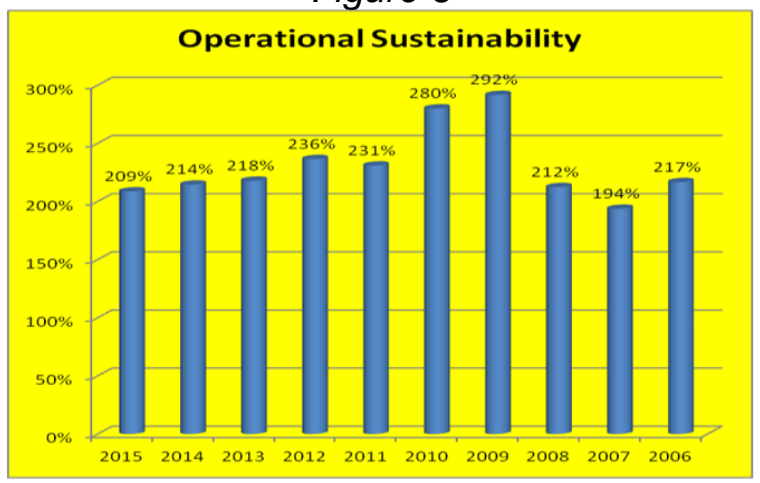

Figure 7

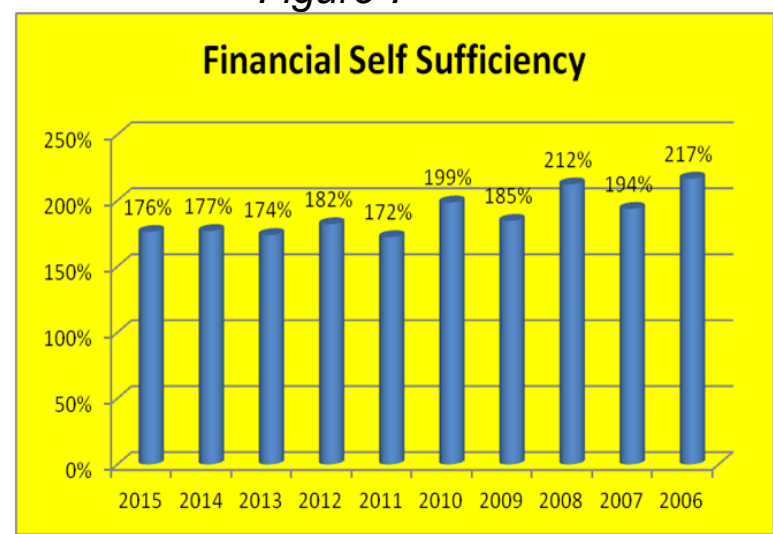

\section{Excellent Profitability, Institutional Strength, Structure of Assets and Operational Strength}

The Financial Performance of cooperatives are measured in terms of four aspects: Profitability, Institutional Strength, Structure of Assets and Operational Strength. These aspects of performance measurement are given points by the CDA to meet ratings ranging form needs improvement to excellent. If the cooperative is able to achieve an excellent rating in all aspects of measurement, it is therefore certain that the organization is assured of sustainability.

\section{CONCLUSION/S}

SPUMC remains to be an organization that is capable of meeting the demands of the current times. The financial performance for the past 10 years indicates that it has the capability to sustain its services taking into focus the ability to be operationally and financially sustainable despite of a satisfactory performance in terms of structure of assets and operational strength and a needing improvement performance in terms of profitability and institutional strength based on the CDA standards.

The study revealed that SPUMC adopts at present a very conservative working capital management. The cooperative is experiencing slow growth and maturity in the life cycle of the cooperative. 


\section{RECOMMENDATION/S}

In view of the above findings and conclusion, the researcher hereby presents the following recommendations:

1. As to financial performance,the management should consider the following:

- develop a comprehensive program which focuses on cost reduction to increase earnings. This will improve performances on EPS, PGR, AER Increase the annual provision for doubtful accounts

- consider financing the current operations utilizing both short and long term borrowings (a little aggressiveness is encouraged)

- intensify efforts to improve collections of accounts for a faster turn over

- adopt a balanced working capital management policy

- adopt value innovation to keep the cooperative from going down in its life cycle

2. The management may focus on finding new ways by which to solution the problem on the decreasing growth rate performance of the cooperative

3. Similar study/ies maybe conducted to extensively look into the life cycle of the cooperative given its current status found in this study. 


\section{References}

Eun C. S., Resnick B. G. (2002) International financial management: Mc Graw Hill International

Saunders, A. (2000) Financial markets and institutions: Prentice Hall International Van Horne J.C. (1998) Financial management and policy: Prentice Hall International Saldana, C. G. (2000) Financial management in the philippine setting: National Book Store

Emery D. G., Finnerty J. D. and Stowe J. D. (1998) Principles of financial management: Prentice Hall

Balatbat M.E.(2011) Management accounting concepts and application: Conanan Bookstore

Brigham Eugene, Houston, Joel F. Fundamentals of financial management. thirteenth ed.2013.

Raiborn, et. Al. (2006) Cost accounting. (6 $6^{\text {th }}$ ed). Thomson Asian Edition

Hilton, R. (2005) Managerial accounting: creating value in a dynamic business environment. ( $6^{\text {th }}$ ed) International Edition

LaMarco, Nicky (2018) The Advantages of a Cooperative Business

websites

https://cda.gov.ph/wp-content/uploads/2021/01/MC2013-15-performance-reportstandards-for-cooperatives.pdf

http://www.mmg.com/en/Sustainability-and-

Community/ /media/Files/sustainability\%20and\%20community/MMG\%20Sustainability\%2 0Report\%202013\%200nline.ashx ,

http://www.ilo.org/wcmsp5/groups/public/---

ed emp/documents/publication/wcms 240640.pdf

www.orau.gov/pbm/handbook/1-1.Pdf)

http://elibrary.worldbank.org/doi/pdf/10.1596/0-8213-3516- 2Borrower viability

http://www.mmg.com/en/Sustainability-and community/ /media/Files/sustainability\%20and\%20community/MMG\%20

Sustainability\%20Report\%202013\%200nline.ashx ,

http://www.ilo.org/wcmsp5/groups/public/--ed emp/documents/publication/wcms 240640.pdf 
https://smallbusiness.chron.com/advantages-cooperative-business-23592.html 